\title{
Corrigendum: Emodin Interferes With AKT1-Mediated DNA Damage and Decreases Resistance of Breast Cancer Cells to Doxorubicin
}

\section{OPEN ACCESS}

Edited and reviewed by: Olivier Feron,

Université catholique de Louvain,

Belgium

${ }^{*}$ Correspondence: Wen Cheng chengwen69@yahoo.com

${ }^{t}$ These authors have contributed equally to this work

Specialty section: This article was submitted to Pharmacology of Anti-Cancer Drugs, a section of the journal

Frontiers in Oncology

Received: 30 March 2021 Accepted: 19 April 2021 Published: 02 June 2021

Citation:

$L i B$, Zhao X, Zhang $L$ and Cheng $W$ (2021) Corrigendum: Emodin Interferes With AKT1-Mediated DNA

Damage and Decreases Resistance of Breast Cancer Cells to Doxorubicin.

Front. Oncol. 11:687841.

doi: 10.3389/fonc.2021.687841

\author{
Bo $\mathrm{Li}^{1 \dagger}$, Xin Zhao ${ }^{2 \dagger}$, Lei Zhang ${ }^{3}$ and Wen Cheng ${ }^{1 *}$ \\ ${ }^{1}$ Department of Ultrasound, Harbin Medical University Cancer Hospital, Harbin, China, ${ }^{2}$ Department of Orthopedics, \\ The Second Affiliated Hospital of Harbin Medical University, Harbin, China, ${ }^{3}$ Department of Ultrasound, The Second Affiliated \\ Hospital of Harbin Medical University, Harbin, China
}

Keywords: AKT1, DNA repair, bioinformatics, breast cancer, emodin

\section{A Corrigendum on}

Emodin Interferes With AKT1-Mediated DNA Damage and Decreases Resistance of Breast Cancer Cells to Doxorubicin

By Li B, Zhao X, Zhang $L$ and Cheng $W$ (2021). Front. Oncol. 10:588533. doi: 10.3389/fonc.2020.588533

In the original article, there was a mistake in Figure $7 \mathrm{C}$ as published. The images in Figure $7 \mathrm{C}$ are incorrectly assembled due to incorrect naming of the image files. The corrected Figure 7 appears below.

The authors apologize for this error and state that this does not change the scientific conclusions of the article in any way. The original article has been updated.

Copyright $\odot 2021 \mathrm{Li}$, Zhao, Zhang and Cheng. This is an open-access article distributed under the terms of the Creative Commons Attribution License (CC BY). The use, distribution or reproduction in other forums is permitted, provided the original author(s) and the copyright owner(s) are credited and that the original publication in this journal is cited, in accordance with accepted academic practice. No use, distribution or reproduction is permitted which does not comply with these terms. 
A
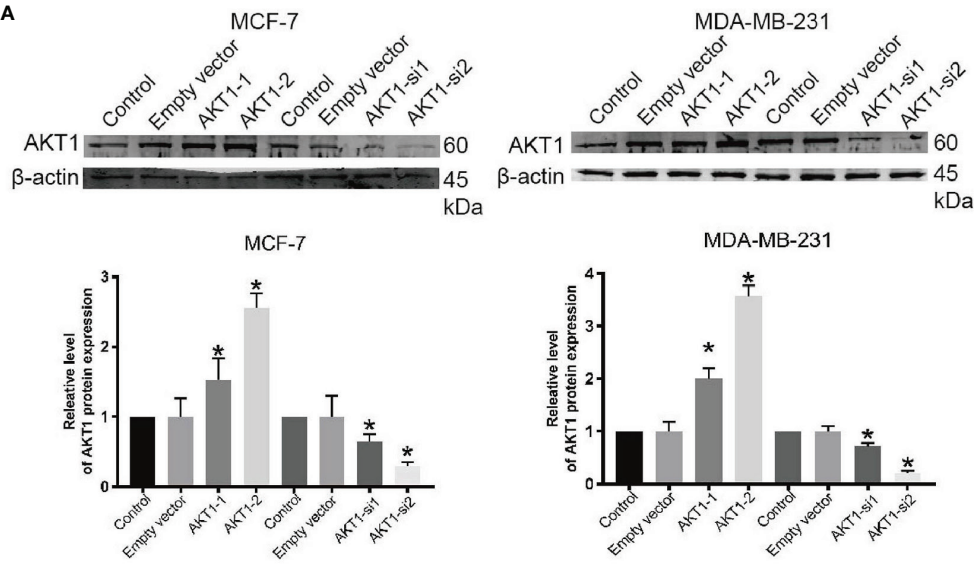

MDA-MB-231
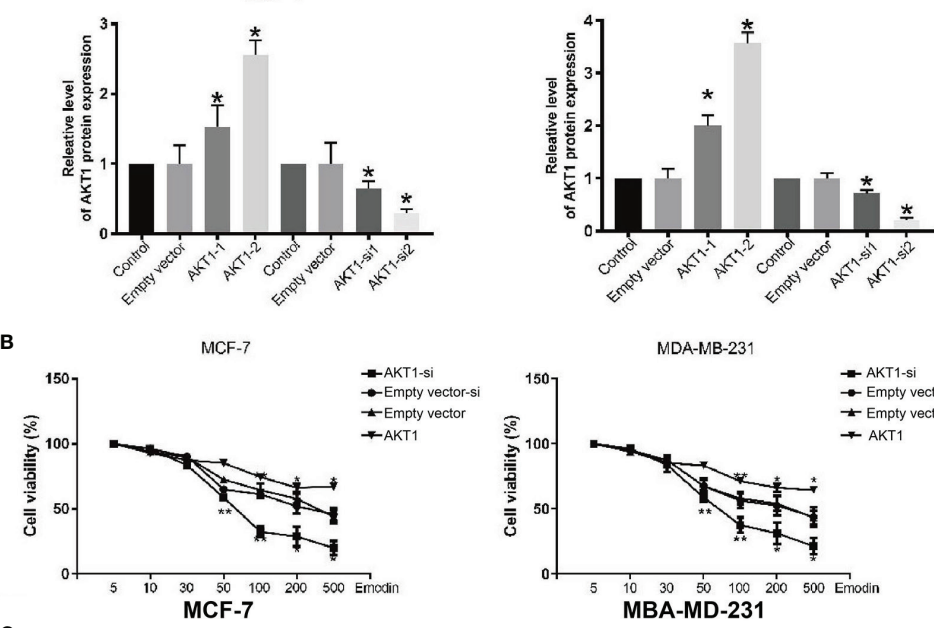

B
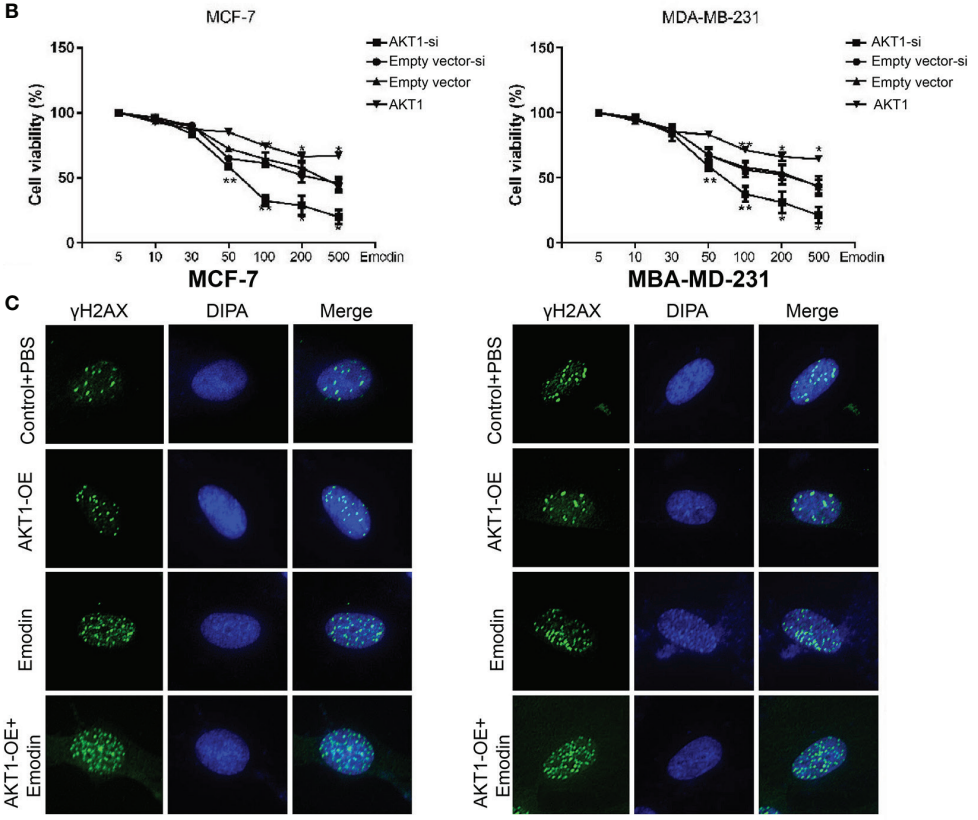

D
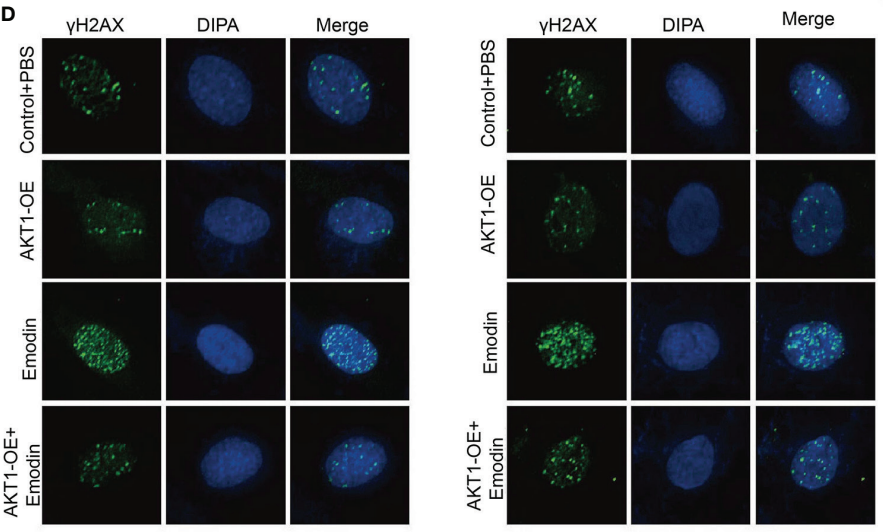

FIGURE 7 | BC cells complemented with AKT-1-si or AKT-1-oe regulated to Emodin. (A) The expression of AKT1 after treatment with AKT1-siRNA or AKT1 overexpression. (B) CCK-8 assay shows the BC cells complemented with AKT1-siRNA or AKT1 over-expression. (C) DNA damage assays shows that the BC cells complemented with AKT1-siRNA promote Emodin compared with cells treated with AKT1-siRNA or Emodin alone. (D) DNA damage assays shows that the BC cells complemented with AKT1 over-expression resists Emodin compared with cells treated with AKT1-overexpression or Emodin alone. The analysis was conducted using the Student's t-test. $p>0.05,{ }^{* *} p<0.01,{ }^{*} p<0.05$. 